\title{
Pathogenicity of Xanthomonas translucens from Annual Bluegrass on Golf Course Putting Greens
}

\author{
N. A. Mitkowski, M. Browning, C. Basu, K. Jordan, and N. Jackson, Department of Plant Sciences, University of \\ Rhode Island, Kingston 02881
}

\begin{abstract}
Mitkowski, N. A., Browning, M., Basu, C., Jordan, K., and Jackson, N. 2005. Pathogenicity of Xanthomonas translucens from annual bluegrass on golf course putting greens. Plant Dis. 89:469-473.

Bacterial wilt of Роа аппиа has been seen increasingly in the Northeast and mid-Atlantic United States in the past few years. The disease causes severe injury to putting greens and can kill large stands of turfgrass. For some time, however, both the bacterial origin of the disease and the causal agent were in doubt. In order to investigate the identity of the causal agent, isolation of the pathogen was undertaken and pathogenicity was confirmed using Koch's postulates on $P$. аппиа. Additional pathogenicity trials then were undertaken to determine the host range of the causal bacterium. Ability of the bacterium to cause disease was restricted to P. аппиа var. аппиа and $P$. attenuata. However, the bacterium was able to survive asymptomatically in vascular systems of $P$. апnиa var. reptans and $P$. trivialis. Experiments to determine the optimal growth temperature of the organism demonstrated that the bacterial growth peaked between 30 and $35^{\circ} \mathrm{C}$. Fatty acid analysis suggested that the bacterium might be a species of Xanthomonas but was inconclusive. Ribosomal RNA analysis demonstrated significant similarity to the American Type Culture Collection isolate of Xanthomonas translucens pv. poae at $99.8 \%$. Comparison of the host range to previously reported data agrees with our molecular findings and indicates that the likely casual organism of bacterial wilt of annual bluegrass is $X$. translucens pv. poae.
\end{abstract}

In much of the northern United States, golf course putting greens are composed of a mixture of bentgrasses, usually creeping bentgrass (Agrostis palustris Huds., also known as A. stolonifera) and the invasive annual bluegrass (Poa annua L.). Because of the expense and difficulty of preventing annual bluegrass encroachment, many golf courses focus on suppressing the production of annual bluegrass seed heads with growth regulators, as opposed to outright $P$. annua removal. Although some $P$. апnиа reduction may be achieved using this tactic, the immediate result is a more consistent and aesthetically appealing playing surface. Thus, mitigation of $P$. апnиа impact is currently more practical than control and putting greens significantly composed of $P$. annua are commonly encountered.

Although $P$. аnnua can provide an excellent putting green playing surface, it is more susceptible to diseases and environmental stresses than $A$. palustris. In the past several years, a bacterial wilt of an-

Corresponding author: N. A. Mitkowski

E-mail: mitkowski@uri.edu

The New England Regional Turfgrass Foundation provided financial support of this research.

Accepted for publication 12 December 2004.

DOI: 10.1094/PD-89-0469

(C) 2005 The American Phytopathological Society nual bluegrass has been observed with increasing frequency in the northeastern United States (3). In 2002, the University of Rhode Island Turfgrass Disease Diagnostic Laboratory identified bacterial wilt on $P$. апnua for approximately $8 \%$ of the disease samples received, primarily from Connecticut but also from Rhode Island, Massachusetts, and Pennsylvania. On putting greens composed of a high percentage of annual bluegrass, this intractable disease was the cause of substantial turf loss.

Symptoms of bacterial wilt begin as lesions formed at the site of infection, typically the ends of the clipped leaves. The bacteria move down into the sheaths to the plant crowns, causing wilting of entire leaves. Eventually, crowns are killed and small patches of dead and dying grass are left behind. On closely cut grasses, leaf lesions are not readily observed, because the bacteria quickly move the short distance into the sheaths and crowns. Symptoms may be confused with anthracnose (Colletotrichum graminicola (Ces.) G. W. Wils.), which also can produce small yellow dispersed patches of dead grass. Bacterial wilt symptoms can be highly variable in color, however, and diagnosis often is difficult because of the lack of organismal signs. Damage usually is most severe on the peripheral or clean-up areas and walkon and walk-off areas of putting greens.

Bacterial wilt of amenity turfgrasses originally was identified in the 1970s on $A$. palustris cv. Toronto in the Chicago area.
The causal organism was identified as Xanthomonas campestris pv. graminis and the only host identified was Toronto C-15 creeping bentgrass (15). Successful control was achieved by overseeding with an alternate creeping bentgrass cultivar (14). In the 1995 revision of the genus Xanthomonas by Vauterin et al., molecular analysis and other factors placed the pathovars of $X$. campestris that infect grasses into the species $X$. translucens (20).

Bacterial wilt was first reported on $P$. annua by Roberts et al. (16). The causal organism of bacterial wilt of $P$. апnиa originally was identified as $X$. campestris pv. poaannua and a number of researchers have evaluated its potential as a biological control in the United States $(8,11,18,21)$. In Japan, a similar disease has been observed and the causal organism has been identified as $X$. campestris pv. poae (13). Researchers in Japan also have experimented with the Japanese isolates for the biological control of $P$. annua $(7,12,13)$.

Beyond the work that originally was undertaken to study $X$. campestris pv. graminis on creeping bentgrass, very little research has been conducted on this emerging disease, particularly as it affects $P$. апnиa (2). The purpose of our research was to identify potential causal agents of bacterial wilt of annual bluegrass in the northeastern United States.

\section{MATERIALS AND METHODS}

Isolation. Cup-cutter plugs of $P$. аnnua plants suspected of being affected by bacterial wilt were dissected and placed under a compound microscope in order to observe bacterial streaming emanating from vascular tissue. Central shoots were removed from infected $P$. annua plants, cut into 1- to 2-mm sections, surface disinfested with $0.6 \%$ sodium hypochlorite solution for $3 \mathrm{~min}$, and plated on nutrient agar (NA) according to the labeled recipe (BD Difco, Sparks, MD). All of the resulting bacteria were streaked onto new NA plates in order to obtain single colonies. From the first round of isolations that occurred in July 2001, a total of 15 bacterial isolates (obtained from the original 15 different colony types) were obtained from diseased grass samples originating in Rhode Island, Massachusetts, Connecticut, New York, and Canada. Pathogenicity testing then was undertaken to satisfy Koch's postulates on 5-month-old $P$. апnиa plants (seed obtained locally from wild 
material) grown in conetainers in the greenhouse. A single colony of rod-shaped, gram-negative bacteria that produced a yellow pigment on YDC agar (recipe according to N. W. Schaad; 19) was identified as pathogenic and designated M-1. Colonies of this isolate did not fluoresce on King's B medium and were unable to ferment glucose anaerobically. Nonpathogenic bacteria were not classified further and it is possible that the same nonpathogenic species was present in multiple isolates. The second isolation was from a cupcutter plug from Alpine Country Club in Cranston, RI taken in August 2003 (APLINE isolate), and the third isolation was from a cup-cutter plug from Pawtucket Country Club in Pawtucket, RI in October 2003 (PAWT isolate). The bacteria originating from these isolations shared the same physiological characteristics as the M-1 isolate.

rDNA sequence analysis. A partial 500-bp 16S rDNA sequence was obtained from the M-1, ALPINE, and PAWT isolates, produced by Microbial ID (Newark, DE) according to their published procedures. Full rDNA sequencing was performed on three bacterial isolates: the M-1 isolate, $X$. translucens pv. graminis (American Type Culture Collection [ATCC] no. 29087), and X. translucens pv. poae (ATCC no. 33804). Polymerase chain reaction (PCR) amplification of the partial 16S rDNA, complete intergenic spacer region, and partial 23S rDNA was accomplished using three separate primer sets. The first primer set, XAN1 (5'-GGAGAGTTAGATCTTGGCTCAG-3')/XAN2 (5'-CCGGGTTTCCCCATTCGG-3'), was taken from Jones et al. (9). These two primers were used to sequence the outer $1,000 \mathrm{bp}$, the set XAN3 (5'-CCCGGTGTAGCAGTGAAATG-3')/XAN4 (5'ATGCAGGTTACTTGTGAGGACG-3') was used to sequence the next 1,000 bp (derived from the PCR product of the XAN1/XAN2 amplification), and the set XAN5 (5'-TACTAGCGATTCCGACTTCATGG-3')/XAN7 (5'-TCCTTAGTTGCCAGCACGTCAT-3') was used to sequence the internal most sequence (derived from the PCR product of the XAN3/XAN4 amplification). Each individual sequence then was assembled to form the contiguous sequence. For DNA extraction, nutrient broth tubes were seeded with bacterial colonies and grown for 5 days at $25^{\circ} \mathrm{C}$. DNA was extracted per Sambrook et al. (17). Ribosomal sequences were amplified using a PTC-100 thermal cycler (Waltham, $\mathrm{MA}$ ) and each reaction tube consisted of a total of $14 \mu \mathrm{l}$ of sterile distilled water, $1 \mu \mathrm{l}$ of template DNA, and PCR reactants supplied by Promega Corporation (Madison, WI), including: $2.5 \mu \mathrm{l}$ of $25 \mathrm{mM} \mathrm{MgCl}$, $2.5 \mu \mathrm{l}$ of magnesium-free buffer, $1.3 \mu \mathrm{l}$ of $200 \mu \mathrm{M}$ dNTPs, and $0.5 \mu \mathrm{l}$ each of $10 \mu \mathrm{M}$ primer. Light mineral oil was added to each tube to cover the reaction mixture.
Tubes were placed into the thermal cycler at $94^{\circ} \mathrm{C}$ and $0.5 \mathrm{U}$ of $\mathrm{Taq}$ DNA polymerase (Promega Corp.) was then added to each tube through the mineral oil. The program for the cycler was as follows: $1 \mathrm{~min}$ at $94^{\circ} \mathrm{C}, 1 \mathrm{~min}$ at $51^{\circ} \mathrm{C}$, and $2 \mathrm{~min}$ at $72^{\circ} \mathrm{C}$ repeated 25 times, followed by $5 \mathrm{~min}$ of extension at $72^{\circ} \mathrm{C}$. After amplification, reaction products were run on a $1 \%$ agarose gel and the amplified DNA was extracted using a Qiagen Gel Extraction kit and an IEC microcentrifuge. Purified DNA from the combined reactions was quantified against a $\Phi$ X174 HaeIII-restricted plasmid standard and sequenced at the Yale University Sequencing Facility using an ABI 3700 automated sequencer.

Pathogenicity testing. For each experiment, five germinated seedlings of each individual grass species were transplanted into each conetainer (measuring 4 by 20.5 $\mathrm{cm}$ ) in a mixture of 80:20 sand:peat. Plants were allowed to grow for 5 months to reach maturity. Fertilizer was applied every 2 weeks and pyrethroid insecticides were sprayed as needed for control of Thrips spp. Plants were clipped at regular intervals to a height of approximately $2 \mathrm{~cm}$. Each experiment was repeated once and used five conetainers containing treated grass and five conetainers containing water controls per grass.

For inoculation, bacteria were streaked on YDC medium and were grown for $72 \mathrm{~h}$ at $22^{\circ} \mathrm{C}$. To harvest, plates were flooded with $1 \mathrm{ml}$ of sterile $0.9 \% \mathrm{NaCl}(\mathrm{aq})$ and colonies were scraped into a test tube with a Nalgene policeman. The bacterial cell suspension was vortexed, and turbidity measured at $640 \mathrm{~nm}$. Concentrations were adjusted to range from $10^{8}$ to $10^{9}$ cells $\mathrm{ml}^{-1}$.

Before plants were inoculated, grass blades were clipped to approximately $1 \mathrm{~cm}$ in length and gently misted. Then, inoculation was performed by submerging leaf tips in a bacterial cell suspension for approximately $15 \mathrm{~s}$. Control plants were treated in the same manner, but dipped in $0.9 \% \mathrm{NaCl}$. Conetainers then were transferred to a greenhouse humidity chamber constructed of thick translucent plastic draped over a wooden frame and lined with a moistened capillary mat using natural lighting. After 1 week, plants were removed from the humidity chamber and transferred to a greenhouse bench for 1 week prior to evaluation. Plants were rated for foliar disease symptoms on a 0 -to-10 scale, where $0=$ unaffected and $10=$ dead. The rating system corresponded approximately to the percentage of affected grass blades, where $5=50 \%$ necrotic. Additional observations were made by examining five symptomatic leaf tips per replicate, excised 2 to $3 \mathrm{~mm}$ below tip lesions, and the base of five central shoots per conetainer for bacterial streaming at $\times 200$ under a compound microscope. In the first experiment, three leaf tips and three central shoot bases from three conetainers were surface disinfested and plated on YDC to confirm the presence of Xanthomonas spp. in inoculated plants. For root inoculations, plant roots were washed free of soil, wounded by clipping, and dipped in the previously mentioned bacterial cell suspension. Plants were maintained in the greenhouse at an average daytime temperature of $32^{\circ} \mathrm{C}$ and $60 \%$ relative humidity for all experiments except for the fourth, in which the average daytime temperature was $18^{\circ} \mathrm{C}$ and the relative humidity was approximately $40 \%$ (as a result of seasonal differences effecting greenhouse conditions). When all three isolates (M-1, ALPINE, and PAWT) were tested simultaneously in a repeated experiment, plants were maintained in the laboratory under florescent lights on a 12-h illumination cycle at approximately $30 \%$ relative humidity and $21^{\circ} \mathrm{C}$.

Four separate experiments to test pathogenicity were performed and each was repeated once. In the first experiment, all bacterial isolates were screened for virulence on $P$. annua. This process identified the M-1 isolate in the first round of screening. This isolate was used to confirm pathogenicity of the other two isolates eventually identified in subsequent repetitions of this experiment. In addition to leaf inoculations, the preliminary screen utilizing the M-1 isolate also incorporated the root inoculation. The second experiment was undertaken to determine the pathogenicity of the M-1 isolate on the perennial biotype of $P$. апnua, $P$. annua var. reptans (Hausskn.) T. Koyama (obtained as mature plugs from a local golf course). The third experiment was similar to the second, but included A. palustris cv. Providence, A. capillaris L. cv. Exeter, P. pratensis L. cv. Lofts 1757, Festuca rubra L. (unspecified cultivar), and Lolium perenne L. cv. Night Hawk. The fourth pathogenicity experiment was undertaken on a collection of Poa spp. that included $P$. annua var. reptans, $P$. compressa cv. Harmony (PI 595588), $P$. compressa L. (PI 618804), $P$. trivialis L. cv. Sabre (PI 594396), P. attenuata Trin. (PI 619560), and P. nemoralis L. (PI 628725). In all experiments, $P$. anпиa var. аппиа was used as a standard for comparison. All seed in the fourth experiment, other than $P$. аnnua, were obtained from the National Germplasm Repository.

Temperature optima. For this experiment, cultures of all three locally collected isolates were incubated on a temperature gradient plate $(5,10)$. A serial dilution of standards ranging from $10^{-4}$ to $10^{-3}$ $\mathrm{CFU} / \mathrm{ml}$ grown in nutrient broth (BD Difco, Sparks, MD) culture was used to produce a linear equation relating absorbance to cell density at $640 \mathrm{~nm}$, measured on a Shimadzu UV-160A UV/VIS spectrophotometer. Absorbance measurements and number of colonies counted were undertaken following 3 days of incubation at 
$25^{\circ} \mathrm{C}$. For the experiment, petri dishes $(5$ $\mathrm{cm}$ ) were filled with $5 \mathrm{ml}$ of sterile nutrient broth and inoculated with $100 \mu \mathrm{l}$ of a 3day-old nutrient broth culture. Six replicates per temperature $(6,10,15,20,25$, 30,35 , and $40^{\circ} \mathrm{C}$ ) were placed on the thermal gradient plate in the dark. Following 24 and $48 \mathrm{~h}$ of incubation, three plates were removed from each temperature series, vortexed, transferred to a cuvette using a pipette, and absorbance measured. Statistical analysis of pathogenicity and temperature data was undertaken using the general linear model procedure of SAS (Cary, NC).

Fatty acid analysis. The M-1 isolate was submitted for cellular fatty acid analysis for species identification. A commercial service, Microbial ID, was used to perform the analysis and isolates were submitted per the preparation instructions of the company.

\section{RESULTS}

Isolation. Three pathogenic bacterial isolates were isolated and designated $\mathrm{M}-1$ (Torrington, CT), ALPINE (Cranston, RI), and PAWT (Pawtucket, RI). Although 15 other unidentified bacteria were isolated at the same time as the M-1 isolate, only three other bacterial colony types (yellow but not mucoid) were cultured on YDC with the ALPINE and PAWT isolates and included one Frateuria sp., one Caulobacter sp., and one Curtobacterium sp. based on Microbial ID rDNA sequencing. None of these bacteria have been reported as being pathogenic and it is likely that these other species were surviving epiphytically on grass shoots or in root tips when isolated. Work by Behrendt et al. (1) demonstrated numerous bacteria existing on the phyllosphere of grassland swards of Poa, Festuca, and Agropyron spp., commonly including those identified in this study (1).

rDNA sequence analysis. A BLAST (NCBI BLAST Web Server) comparison of the rDNA sequences of the M-1 isolate indicated considerable similarity to three GenBank accessions: AF209764 (X. translucens pv. unspecified), X99299 (X. translucens pv. translucens), and X99298 (X. translucens pv. graminis). However, only a limited number of nucleotides were submitted under these accessions, preventing a complete comparison from being made. A comparison of the M-1 isolate (GenBank accession AY253329) and the X. translucens pv. graminis sequence (ATCC no. 29087; GenBank accession AY247064) was performed and demonstrated a nucleotide similarity of $99.1 \%$ (data not shown). Of the 2,190 nucleotides sequenced, three transitions, 11 transversions, and five indels were identified. A comparison of the M-1 isolate and the $X$. translucens $\mathrm{pv}$. poae sequence (ATCC no. 33804; GenBank accession AY572961) demonstrated a nucleotide similarity of $99.8 \%$ (differences were identified as one transition, two transversions, and two indels). The majority of total polymorphisms occurred between base pairs 1,701 to 1,712 , located in the internal transcribed spacer (ITS)-2 region, which is highly polymorphic among Xanthomonas spp. (6). Comparison of the 500-bp 16S rDNA region of the M1, ALPINE, and PAWT sequenced by Microbial ID demonstrated $100 \%$ similarity between the M-1 and ALPINE isolate and a single $A$ to $G$ transversion between the M-1 and PAWT isolate at base pair 481 .

Pathogenicity testing. In the first experiment, of the 15 isolates tested, only the M-1 isolate was found to be pathogenic on $P$. annua var. annua. Bacterial streaming from the bases of symptomatic central shoots, confirming infection, was observed only in the inoculated $P$. апnиa var. annua plants in $88 \%$ of the shoots examined $(n=$ 25 ). Infected plants had a disease rating of $8.2 \pm 2.1$ and $8.1 \pm 0.9$ (initial and repeated trial) compared with the control plants, which had a disease rating of $1.2 \pm 0.8$ and $0.8 \pm 0.5$. Koch's postulates were satisfied through reisolation. Root inoculations did not result in disease symptoms and no bacterial streaming from excised roots or central shoots was evident. This experiment was repeated for the M-1, ALPINE, and PAWT isolates in the laboratory (Table 1).

In the second experiment, pathogenicity of the M-1 isolate was examined on $P$. annua var. annua and $P$. annua var. reptans. Disease symptoms were evident only on inoculated $P$. annua var. annua, with bacterial streaming observed from the central shoots of 100 and $92 \%$ (initial and repeated trial, respectively) of the inocu- lated $P$. апnиa var. апnиa plants examined $(n=25)$. Inoculated $P$. апnиa var. апnua plants had an average disease rating of 8.5 \pm 0.6 and $8.0 \pm 0.9$ compared with control plants, which had a disease rating of $0.9 \pm$ 0.7 and $0.6 \pm 0.3$.

In the third experiment, disease was observed only on inoculated $P$. annua var. anпиа. Bacterial streaming from bases of the central shoots was observed in $100 \%$ (initial and repeated trial) of the $P$. аппиа var. annua plants examined $(n=25)$. The M-1 isolate was unable to infect Agrostis palustris, A. capillaris, Poa pratensis, Festuca rubra, and Lolium perenne. All of these plants were symptomless after 2 weeks and bacterial streaming was not observed in excised central shoots. Disease also was not observed on untreated $P$. annua control plants. A quantitative measure of disease was not recorded for the first trial of this experiment; however, diseased plants were similar in appearance to those in both the second and third experiment. In the second trial of this experiment, infected $P$. апnиa var. annua plants had an average disease rating of $8.1 \pm 0.4$ and control plants had a disease rating of $0.7 \pm$ 0.2 . All other species had a disease rating of 0 , regardless of whether they were inoculated or control plants.

In the fourth experiment, comparing susceptibility of a number of Poa spp., $P$. annua var. annua and $P$. attenuata were the only grasses demonstrating symptoms of bacterial wilt (Table 2); specifically, wilting and tip dieback. Bacterial streaming from bases of central shoots was observed in 82 and 94\% (initial and repeated trial, respectively) of the shoots examined ( $n=$

Table 1. Pathogenicity of three isolates of Xanthomonas translucens pv. poae on Poa annua var. annи $a^{\mathrm{x}}$

\begin{tabular}{lcc}
\hline Isolate (source) & ${\text { Symptomatic shoots }(\%)^{\mathbf{y}}}^{\mathbf{y}}$ & ${\text { Streaming from shoot bases }(\%)^{\mathbf{z}}}^{\text {Control }}$ \\
ALPINE (Cranston, RI) & $1.7 \mathrm{a}$ & $0.0 \mathrm{a}$ \\
M-1 (Torrington, CT) & $57.5 \mathrm{c}$ & $85.0 \mathrm{c}$ \\
PAWT (Pawtucket, RI) & $27.5 \mathrm{~b}$ & $45.0 \mathrm{~b}$ \\
\hline
\end{tabular}

${ }^{x}$ Values in a column with the same letter are not statistically different according to Tukey's standardized range test $(P<0.01)$.

${ }^{\text {y }}$ Five symptomatic shoot bases were examined from each conetainer (pooled $n=40$ ) to determine the proportion with bacterial streaming.

${ }^{\mathrm{z}}$ Data were pooled from the initial and repeated trial of the experiment.

Table 2. Mean disease rating for Poa spp. inoculated with the M-1 isolate of Xanthomonas translucens pv. poae

\begin{tabular}{lcc}
\hline & \multicolumn{2}{c}{ Disease rating $^{\mathbf{z}}$} \\
\cline { 2 - 3 } Species & Inoculated & Control \\
\hline Poa annиa var. annua & $7.7 \mathrm{a}$ & $1.6 \mathrm{~b}$ \\
P. annиa var. reptans & $1.0 \mathrm{~b}$ & $1.0 \mathrm{~b}$ \\
P. compressa (PI 618804) & $1.1 \mathrm{~b}$ & $1.8 \mathrm{~b}$ \\
P. compressa cv. Harmony & $0.9 \mathrm{~b}$ & $0.8 \mathrm{~b}$ \\
P. attenuata (PI 619560) & $5.6 \mathrm{a}$ & $0.9 \mathrm{~b}$ \\
P. nemoralis (PI 628725) & $2.5 \mathrm{~b}$ & $1.0 \mathrm{~b}$ \\
$P$. trivialis cv. Sabre & $1.9 \mathrm{~b}$ & $2.2 \mathrm{~b}$ \\
\hline
\end{tabular}

${ }^{\mathrm{z}}$ Disease symptoms were assessed on a 0 -to- 10 scale, where $0=$ unaffected and $10=$ dead. Data were pooled from the initial and repeated trial of the experiment. Values with the same letter are not statistically different according to Tukey's standardized range test $(P<0.01)$ within columns or rows. 
25) from $P$. апnиa var. апnua and 44 and $62 \%$ (initial and repeated trial, respectively) from $P$. attenuata. Although exhibiting no symptoms of wilt, bacterial streaming was seen from the examined stem bases of 16 and $7 \%$ of inoculated $P$. trivialis plants, 16 and $12 \%$ of inoculated $P$. annua var. reptans plants, and 12 and $0 \%$ of Poa annua var. annua control plants in the first and second trials, respectively.

Temperature optima. The optimal temperature for growth of the M-1 isolate occurred between 30 and $35^{\circ} \mathrm{C}$ (Fig. 1). In laboratory experiments, growth peaked around $31^{\circ} \mathrm{C}$ when cultures were examined at $24 \mathrm{~h}$ and $34^{\circ} \mathrm{C}$ when cultures were examined at $48 \mathrm{~h}$. Very little growth occurred below 20 or above $40^{\circ} \mathrm{C}$.

Fatty acid analysis. Fatty acid analysis using the Microbial Identification System employed by Microbial ID determined that the M-1 isolate had a similarity index to $X$. axonopodis pv. vesicatoria of 0.124 (with a similarity index of 0.6 or higher representing the same species). There was no similarity to the profile for $X$. translucens pv. graminis stored in the database and only a 0.086 similarity index to $X$. translucens pv. translucens. The isolate was retested by Microbial ID 6 months after the initial submission to ensure that only a pure culture was present and similar results were obtained. The Microbial ID database does not contain a profile for $X$. translucens pv. poae.

\section{DISCUSSION}

Based on sequencing of rDNA, this study has demonstrated that the isolated bacteria were $X$. translucens pv. poae. Pathogenicity testing of the three isolates and comparison of the results to the published host range determined by Nishino and Fujimori (12) provide further evidence

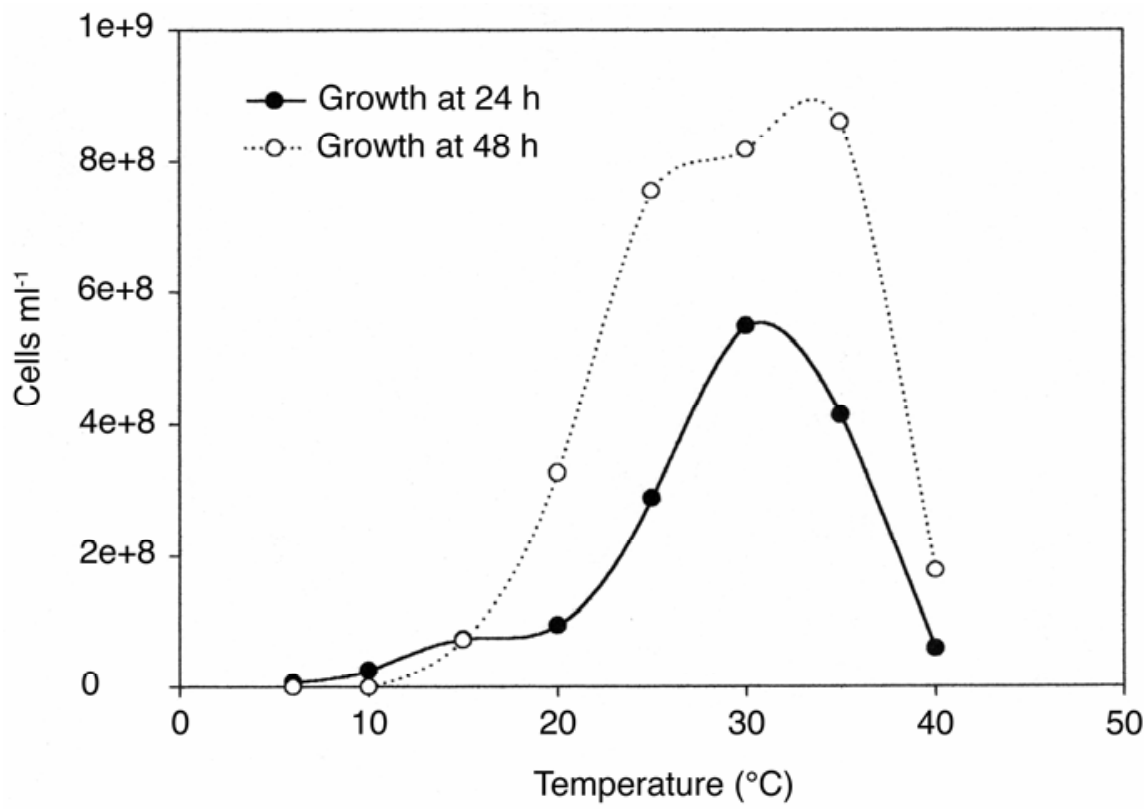

Fig. 1. Temperature-dependent growth curve for the M-1 isolate of Xanthomonas translucens pv. poae.

that the isolates are $X$. translucens pv. poae, suggesting that $X$. translucens pv. poae is the most likely causal agent of bacterial wilt of annual bluegrass. The work of Nishino and Fujimori (12) demonstrated that both the ATCC isolate of $X$. translucens pv. poae (ATCC no. 33804) and Japanese isolates of $X$. translucens pv. poae can cause disease on $P$. аппиа, $P$. trivialis, $P$. supina, and $P$. ampla (12). They also determined that, although the bacteria did not cause disease on $P$. pratensis, $P$. compressa, $P$. secunda, and $P$. bublosa, the organism did multiply in leaf tips, never moving into sheaths or crowns. This study did not incorporate experiments on P. ampla, P. bublosa, $P$. secunda, or $P$. supina, because they could not be obtained at the time. In the current study, the Connecticut isolate (M-1) caused disease on $P$. annua var. annua and $P$. attenuata (which was not included in previous studies by other researchers), infecting both sheaths and crowns. It did not cause disease on $P$. compressa, $P$. nemoralis, or $P$. pratensis. Although disease was not observed in $P$. trivialis or $P$. annua var. reptans, limited bacterial streaming was observed in a small percentage of their central shoots. Although it is unclear why disease did not develop on $P$. trivialis, it is possibly that the M-1 isolate is a strain distinct from the Japanese isolates with altered virulence. Nishino and Fujimori (12) observed significant differences in virulence between at least two native Japanese isolates of $X$. translucens pv. poae.

Savage et al. (18) indicated that differences between the host range of their American isolate and $X$. translucens pv. poae were significant enough to establish the pathovar $X$. translucens pv. poaannua, but Nishino et al. (13) was unable to confirm significant differences using the iso-

472 Plant Disease /Vol. 89 No. 5 late of Savage et al. (XCPA; 13,18). Unfortunately, Savage et al. (17) did not indicate exactly which species or cultivars their isolate was tested on in the published report. Both our rDNA and pathogenicity results agree with Nishino et al. that the correct pathovar name is $X$. translucens pv. poae (13).

De Cleene et al. (4) published a detailed description of the host range of $X$. translucens pv. graminis. Their results indicate that its primary hosts are $L$. perenne, $L$. multiflorum L., Phleum pratense L., and $F$. pratensis Huds. In the present study, $L$. perenne was the only grass species examined that appears on the list of De Cleene et al. (4), but it was determined not to be a host of the New England isolates. This single piece of evidence does not exclude the isolates identified in New England from being $X$. translucens pv. graminis, but does suggest that it is unlikely in the context of the additional information presented here. The only report of $X$. translucens pv. graminis in the United States is from A. palustris cv. Toronto and indicates that the bacteria would not reproduce on any other hosts, including Lolium spp. (14). This would suggest that these authors misidentified this pathogen; thus, $X$. translucens pv. graminis has not yet been identified in the United States.

Fatty acid analysis was inconclusive. Although it did suggest that the M-1 isolate was a Xanthomonad, the similarity to existing profiles in the Microbial ID database was very low, in contrast to the rDNA analysis. This suggests that fatty acid analysis may not be a useful tool for identification of $X$. translucens pv. poae or that the Microbial ID database does not contain a representative sample of Xanthomonad profiles.

Bacterial wilt typically has been considered a stress-related disease on golf course putting greens (exacerbated by low cutting heights and excessive compaction); however, we were able to induce dramatic disease in the greenhouse on extremely vigorous plants (N. Jackson, personal observation). $P$. аnnua plants grown at a 2to $3-\mathrm{cm}$ height of cut in a sand-based media were extremely susceptible to leaf wilting and crown rotting caused by $X$. translucens pv. poae. In addition, allowing inoculated grass to grow to $10 \mathrm{~cm}$ did not mitigate disease symptoms after infection (data not shown). Symptoms were most dramatic under conditions of high humidity and average temperatures of $30^{\circ} \mathrm{C}$, when artificially inoculated with high levels of bacteria. These observations correspond to the in vitro temperature optima data reported in this article and coincide with the highest incidence of disease in the field. Even under suboptimal conditions of low humidity and temperatures of approximately $18^{\circ} \mathrm{C}$ (as experienced in the first trial of the fourth experiment), leaf wilting did occur. Under suboptimal conditions, 
however, plants remained asymptomatic for a longer period of time than under optimal conditions ( 2 to 4 weeks longer), though bacterial streaming could be identified in the majority of leaves, sheaths, and plant crowns within 2 weeks of inoculation.

Isolation of the pathogen initially was difficult because the medium used for isolation, NA, allowed many nonpathogenic bacteria present to grow. Additionally, the causal Xanthomonad grew much more slowly than the epiphytic and soilborne bacteria, quickly becoming overwhelmed and unrecoverable. When the semiselective medium YDC was employed for further isolations, the process became less difficult. Unfortunately, isolation timing appears to play a role in isolation success. When isolations are made early in the infection, Xanthomonas spp. are the predominant bacteria recovered. When a sample is considerably degraded by the effects of wilting, many more epiphytic or saprobic bacteria are recovered. Difficulty isolating this bacterium has not been reported by other researchers.

The ability of this organism to fully colonize the $P$. апnua vascular system yet fail to produce dramatic disease symptoms under suboptimal conditions suggests that it may be widely prevalent on golf courses and remain undetected. It also suggests that $P$. апnua plants in natural surroundings may harbor the pathogen asymptomatically in a highly evolved parasitic relationship. In addition, low levels of infection (in the absence of disease) also occurred in $P$. trivialis and $P$. annua var. reptans in the last experiment, suggesting that tolerant hosts may regularly harbor the organism. Nishino and Fujimori demonstrated bacterial multiplication in leaf tips of numerous nonhost grasses in the absence of expressed disease (12). Although only a few species of Poa were examined for susceptibility in this experiment, it is quite probable that other hosts do exist in natural surroundings, providing an additional reservoir for the pathogen. $P$. attenuata was severely affected by the pathogen but is not native to the United States.

Although mowers probably provide the most efficient means of pathogen transmission, as well as producing entry wounds, it appears that insects can transfer the bacterium. In the first trial of the last experiment, disease symptoms started to develop on a small percentage of $P$. апnиa control plants 4 weeks after inoculation (inoculated plants developed disease symptoms within 2 weeks of inoculation). Disease was limited to minimal tip die-back and streaming could not be detected outside of diseased tissue. The most probable explanation for this disease transmission was an infestation of thrips present at the time.
The amount of inoculum transmitted by these insects would have been minimal compared with the dipping procedure used on the treated plants, providing an explanation for the slow spread of the disease within the control plants. It is unlikely that splash transmission occurred because plants were separated by a distance of a meter and were grown in conetainers a half-meter off the greenhouse bench surface.

Molecular differences between the M-1 isolate of $X$. translucens pv. poae and the ATCC isolate of $X$. translucens pv. graminis were significant enough to indicate that it may be possible to develop molecular markers to separate $X$. translucens pathovars. The pathovar distinction is not considered a taxonomic level of classification; however, the fact that some ITS variation exists between at least two $X$. translucens pathovars suggests that the taxonomic applicability of the pathovar distinction may need further investigation.

Our work provides an initial basis for the use of rDNA markers to separate $X$. translucens pathovars. Isolation of these bacteria can be difficult because multiple species of yellow bacteria can be isolated from grass leaves and pathogenicity testing of each isolate is extremely tedious. Development of reliable molecular markers could greatly increase the speed and ease of identification. Additional testing of $X$. translucens pathovars will need to be undertaken to determine the utility of rDNAtargeted PCR primers.

Additional research is needed to confirm that $X$. translucens pv. poae is the proper pathovar designation for the bacterium isolated and it is the only bacterial species involved in causing bacterial wilt of annual bluegrass in the northeastern United States. Additional isolates should be collected and tested for pathogenicity using a full range of host species, focusing on those used in previous studies. To date, the only plant pathogen identified from our isolations was a Xanthomonas sp.; however, this does not rule out the possibility of the involvement of additional bacterial species. In order to conclusively determine the identity of all three Xanthomonas isolates, the full 2,190-bp rDNA sequence will be generated from the ALPINE and PAWT isolates.

\section{LITERATURE CITED}

1. Behrendt, U., Muller, T., and Seyfarth, W. 1997. The influence of extensification $\mathrm{n}$ grassland management on the populations of microorganisms in the phyllosphere of grasses. Microbiol. Res. 152:75-85.

2. Browning, M., Mitkowski, N. A., and Jackson, N. 2002. Xanthomonas spp. affecting golf course putting greens in the Northeast. (Abstr.) Phytopathology 92:S10.

3. De Cleene, M., Leyns, F., Van Den Mooter, M., Swings, J., and De Ley, J. 1981. Reaction of grass varieties grown in Belgium to Xan- thomonas campestris pv. graminis. Parasitica 37:29-34

4. Dernoeden, P. H., Jackson, N., Mitkowski, N., and Kaminski, J. E. 2002. Bacterial wilt: An enigmatic annual bluegrass disease of putting greens. Golf Course Manage. January 2002:177-180.

5. Englander, L., and Turbitt, W. 1979. Increased chlamydospore production by Phytophthora cinnamomi using sterols and near-ultraviolet light. Phytopathology 69:813-817.

6. Goncalves, E., and Rosato, Y. 2002. Phylogenetic analysis of Xanthomonas species based upon 16s-23S rDNA intergenic spacer sequences. Int. J. Syst. Evol. Microbiol. 52:355361 .

7. Imaizumi, S., and Fujimori, T. 1999. Field spread and longevity of Xanthomonas campestris pv. poae (JT-P482) after inoculation to annual bluegrass and mowing. Ann. Phytopathol. Soc. Jpn. 65:57-59.

8. Johnson, B. J. 1994. Biological control of annual bluegrass with Xanthomonas campestris pv. poaannua in Bermudagrass. HortScience 29:659-662.

9. Jones, J. B., Bouzar, H., Stall, R. E., Almira, E. C., Roberts, P. D., Bowen, B. W., Sudberry, J. Stickler, P. M., and Chun, J. 2000. Systematic analysis of xanthomonads (Xanthomonas spp.) associated with pepper and tomato lesions. Int J. Syst. Bacteriol. 50:1211-1219.

10. Leach, C. M. 1967. Interaction of near-ultraviolet light and temperature on sporulation of the fungi Alternaria, Cercospora, Fusarium, Helminthosporium and Stemphylium. Can. J. Bot. 45:1999-2016.

11. Neal, J. N., Zhou, T., and Williams, N. D. 1992. Annual bluegrass control with Xanthomonas campestris pv. poannua. Progr. Proc. N. Y. State Pest Manage. Conf. 55:6-14.

12. Nishino, T., and Fujimori, T. 1998. Pathogenic diversity of Xanthomonas campestris pv. poae within the genus Poa. Ann. Phytopathol. Soc. Jpn. 64:1-6.

13. Nishino, T., Imaizumi, S., Miyabe, K., Yamada, M., and Goto, M. 1995. Xanthomonas campestris pv. poae as the causal agent of wilt symptoms on annual bluegrass in Japan. Ann. Phytopathol. Soc. Jpn. 61:555-561.

14. Roberts D. L., and Vargas, J. M. 1984. Bacterial wilt: a potentially devastating threat. Golf Course Manage. April 1984:33, 37-41

15. Roberts, D. L., and Vargas, J. M. 1984. Antigenic relatedness of the North American Toronto bentgrass bacterium to Xanthomonas campestris pv. graminis from Europe. (Abstr.) Phytopathology 74:813.

16. Roberts, D. L., Vargas, J. M., and Detweiler, R. 1985. Occurrence of bacterial wilt on Poa annua and other turfgrasses. (Abstr.) Phytopathology 75:1289.

17. Sambrook, J., Fritsch, E. F., and Maniatis, T. 1989. Molecular Cloning: A Laboratory Manual, v. 1-3. Cold Spring Harbor Laboratory Press, Cold Spring Harbor, NY.

18. Savage, S. D., Haygood, R. A., and Mitchell, K. D. 1993. Evaluating the suitability of Xanthomonas campestris pv. poaannua as a biocontrol agent for annual bluegrass (Poa annua). (Abstr.) Phytopathology 83:1339.

19. Schaad, N. W. 1980. Laboratory Guide for Identification of Plant Pathogenic Bacteria. American Phytopathological Society, St. Paul, MN.

20. Vauterin, L., Hoste, B., Kersters, K., and Swings, J. 1995. Reclassification of Xanthomonas. Int. J. Syst. Bacteriol. 45:472-489.

21. Zhou, T., and Neal, J. C. 1995. Annual bluegrass (Poa annua) control with Xanthomonas campestris pv. poaannua in New York State. Weed Technol. 9:173-177. 